\title{
Factors Influencing the Willingness to Pay for Entrance Permit: The Evidence from Taman Negara National Park
}

\author{
Zaiton Samdin (Corresponding author) \\ Institute of Tropical Forestry and Forest Products (INTROP) \\ Universiti Putra Malaysia, 43400, Serdang, Selangor, Malaysia \\ Tel: 6-03-8947-2183Ｅ-mail: zaisa@econ.upm.edu.my \\ Yuhanis Abdul Aziz \\ Faculty of Economics and Management \\ Universiti Putra Malaysia, 43400, Serdang, Selangor, Malaysia \\ Tel: 6-03-8946-7874Ｅ-mail: anis@econ.upm.edu.my \\ Alias Radam \\ Faculty of Economics and Management \\ Universiti Putra Malaysia, 43400, Serdang, Selangor, Malaysia \\ Tel: 6-03-8946-7733 E-mail: alias@econ.upm.edu.my \\ Mohd Rusli Yacob \\ Faculty of Economics and Management \\ Universiti Putra Malaysia, 43400, Serdang, Selangor, Malaysia \\ Tel: 6-03-8946-7646 E-mail: mroy@econ.upm.edu.my
}

\begin{abstract}
Non-market techniques such as Travel Cost Method (TCM) and Contingent Valuation Method (CVM) are commonly used to estimate the economic benefits of outdoor recreation. This study applied the CVM, with Willingness to Pay (WTP) as the elicitation method, to investigate the pattern of willingness to pay among visitors of Taman Negara National Park (TNNP). In applying CVM, the respondents were asked on the maximum amount they were willing to pay to enter this park. Data were obtained using closed-ended questionnaires through interview. About 196 visitors were involved in the study. This study used multiple regressions (MR) to investigate factors that determine WTP for entrance permit in TNNP. This study found that the WTP was positively related to several important factors; and these factors include nationality, income, education and marital status. All these factors can help to explain the WTP for entrance permit at TNNP. Approach in determining WTP for entrance permit will help park authorities to be more financially self-sufficient. In addition, it will generate more income, and thus more efficiency in operating and maintaining the national parks.
\end{abstract}

Keywords: Willingness to pay, Contingent Valuation Method, Multiple regressions, National park, Entrance permit

\section{Introduction}

The most important recent issue for national parks is that of inappropriate entrance fees. This creates several problems in parks; the most common is a lack of income generation. Sources of information such as knowledge of visitor profile, trip characteristics, and paying characteristics are important for any development plan at protected areas and national park. The data on visitor profile is useful in identifying target groups, so that the relevant authority can develop more specific guidelines and plans in promoting and marketing.

In general, the purpose and scope of this study is to investigate factors that determine visitors' willingness to pay using Contingent Valuation Method (CVM) at Taman Negara National Park (TNNP). Multiple regression (MR) is one of the mathematical tools that can be used to estimate the association between demographic and economic factors and the willingness to pay for entrance permit at national parks. The results of the MR can be used as inputs in the planning process. For example, information on factors affecting WTP can be used by the management to develop more effective plans for the TNNP, which in turn can be used to provide rationale for decisions, guides for action and a standard of performance. This paper consists of 6 sections. The first section will focus on the general orientation of the study. Section 2 will discuss on Contingent Valuation Method (CVM). Section 3 will focus on TNNP. Section 4 will focus on materials and method. Section 5 discusses results of MR and factors influencing WTP among visitors will be identified. Finally, Section 6 will formulate conclusions.

\section{Contingent Valuation Method}

Non-market valuations such as the Contingent Valuation Method (CVM) have helped to assign dollar values to non-use values for these goods which, unlike other products, are not traded in the market. CVM is commonly used in the valuation of public goods (Mitchell and Carson, 1989) and is capable of measuring both types of 
value of resources: use value and non-use value (White and Lovett, 1999). These may include entry to national/recreational parks, conservation of endangered species or cultural heritage. Recently, Willingness to Pay (WTP) has been used as a guideline to develop an efficient pricing system of protected areas and routinely identified through a questionnaire-based approach (Cameron, 1988). White and Lovett (1999:2) add that:

It does this by setting up a hypothetical market in which people are asked to state monetary bids for various goods (willingness to pay) based on the information provided to them. The underlying assumption is that people are able to translate a wide range of environmental criteria into a single monetary amount representing the total value to them of a particular resource, and the more they value it the more they will be willing to pay for it.

$C V M$ can be employed to measure the benefits of using park resources, for, for instance, recreational activities and natural amenities. Even though non-market valuation such as CVM has been used since the middle of the last century, it is still widely employed at the present time (Mathews et al., 2001). It started when there was a concern about recreation, and thus a need to put a monetary value on it (Clawson, 1958, in Mathews et al., 2001). Mathews et al. (2001:327) identify it as:

One type of method used to uncover these underlying preferences for environmental resources associates consumption of a related market good in order to estimate the value of the non-market good or service.

\section{Taman Negara National Park (TNNP)}

TNNP straddles the borders of Kelantan, Terengganu and Pahang in Peninsular Malaysia. It was declared as a national park, through enactments by the states of Pahang, Kelantan and Terengganu in 1938/39 and given the name King George V National Park (Rubeli, 1976). It is claimed to be home to one of the oldest tropical rain forests in the world. According to Department of Wildlife and National Park (DWNP, 1989), it is Peninsular Malaysia's greatest national park and covers an area of 4,343 sq km. After Malaysia's independence in 1957, the name was changed to Taman Negara, which means 'national park' (DWNP, 1986; 1987).

\subsection{Profile of visitors}

It was discovered that trends and visiting pattern are changing; the current trend is for more international visitors to visit TNNP. This is in contrast with the previous times, when more Malaysian visitors visited the park. Table 1 shows that in 2009 there was a total of 46057 international visitors (53.1\%) compared to 40617 Malaysian visitors (46.9\%). Table 2 shows visitor arrivals at TNNP in 2009 by nationality. International visitors to TNNP were dominated by the Dutch, followed by the British and the German. Others were from France and Singapore.

Insert Table 1 about here

Insert Table 1 about here

\subsection{Charges for permits and licences at TNNP}

Recently, TNNP has implemented several changes to the payments for permits and licences issued to their visitors. These cover entrance permits, fishing licences, camera licences, camping fees, the canopy walkway and the hide. Visitors are entitled to enter the park for a month on payment of RM1 as an entrance permit. This study will focus only on entrance permit. Other charges are shown in Table 3.

Insert Table 3 about here

\subsection{Social and natural features}

Gunung Tahan, the highest mountain in Peninsular Malaysia, is located in TNNP. The park's elevation ranges from $61 \mathrm{~m}$ up to $2187 \mathrm{~m}$ above sea level. The mountains are the physical feature of the central and eastern parts of the park. Limestone hills and caves are also found at scattered locations, mostly in the western, southern and eastern parts of TNNP. Lowland areas exist only in the north and south of the park. These lowland areas, which are between $120 \mathrm{~m}$ and $30 \mathrm{~m}$ above sea level, comprise about $10 \%$ and $57 \%$ of TNNP. The western part is Gunung Peringat, Gunung Luas is in the south, while the eastern part is Gunung Biwah. The highest limestone hill in the country is Gua Peringat. There are several limestone caves in TNNP, including Gua Telinga, Gua Kepayang, Gua Daun Menari, and Gua Luas near the Kuala Tahan park headquarters. Gunung Tahan is the main watershed for six major rivers: Sungai Tahan, Leber, Kenyam, Sat, Sepia and Relau.

According to Kochummen (1990) all types of forest vegetation are found in TNNP, except coastal wetland forests, mangroves and peat swamp forests. The types of tropical rain forest in TNNP are lowland dipterocarp forest, hill dipterocarp forest, montane oak and laurel forest, and montane ericaceous forest in the central mountainous regions (Soepadmo, 1971; Kochummen, 1990). Wildlife in this park includes hundreds of species of large and small mammals, birds, amphibians, reptiles, freshwater fish and insects (Khan, 1971). Large mammals, such as the Asian elephant, the Sumatran rhinoceros and tapir, and small mammals like the mouse deer, squirrels and bats can be found in the park (Lim and Anan, 1990). In 1982, Davison reported that 254 species of bird had been found in TNNP. These included hornbills, eagles and woodpeckers. According to Ismail (1984) a total of 109 species of fish have been identified at TNNP. Also, 58 species of reptiles and 56 species of amphibians have been seen there; these include vipers and freshwater turtles. 


\subsection{Access and activities}

TNNP can be reached by road, rail or boat. If visitors decide to go there by road, the journey from Kuala Lumpur to Jerantut, which is the nearest town, takes about 3 hours. From Jerantut, visitors travel to the Kuala Tembeling Jetty, which is another 16 kilometres. Train services are available from Kuala Lumpur and Singapore. The train stops at Kuala Tembeling train station.

Various activities can be undertaken by visitors to TNNP. The recreational activities include the canopy walkway, hides and cave exploration. TNNP has the longest canopy walkway in the world; it is suspended 40 metres above the ground. Visitors can also stay overnight at hides and observe wildlife visiting the salt licks nearby. If they want to go exploring they can go to beautiful caves such as Gua Peningat, Gua Telinga and Gua Besar. River exploration is one of the most exciting activities, and a boat trip can be taken to Sungai Tembeling from Kuala Tahan. Visitors can also climb Gunung Tahan, which is the highest peak in Peninsular Malaysia.

\section{Materials and Method}

Regression analysis is a method that analyzes the relationships among variables that are represented in the form of an equation, called a regression equation. It is widely used with numerical variables (interval variables) and has become one of the most common methods of analyzing data in the social sciences. It is a set of statistical techniques which allows us to access the relationship between one dependent and several independent variables (Tabachnick and Fidell, 2001). According to Bryman and Cramer (2001:185) 'regression is a powerful tool for summarizing the nature of the relationship between variables and for making predictions of likely values of the dependent variable'. The main idea of regression is to produce a line that measures the relationship between the variables.

The main purpose of multiple regression (MR) is to give a researcher the opportunity to learn more of the relationship between dependent and independent variables (predictors). For many years MR has been used in various disciplines. For example, Woehr and Cavell (1993) used it to predict the test score in an introductory psychology class. In tourism, there are several examples of studies using MR. Tisdell and Wilson (2000) used this method to identify several factors that had influenced WTP among visitors to a conservation programme for sea turtles in Mon Repos, Australia. In this study, the qualification of education was found to be the most important factor, followed by income and donations contributed towards conservation. Kosz (1996) also used MR to estimate the WTP among visitors to 'Donau-Auen' national park. He discovered that the amount of WTP depended significantly on the professional standing of the respondent and also on age, personal income, the number of children living in the same household, the residential area and plans for future visits. Lindsey and Holmes (2002) studied tourist support for marine protection in Nha Trang, Viet Nam. The WTP for protection was highly influenced by education and income. They also found that foreign tourists were willing to pay more. In the context of Malaysian tourism, Zaiton (2007) found that WTP for entrance permit at TNNP was distinctively influenced by nationality, income, education and contribution to any environmental organization. Mohd Shahwahid and Mahamad Yusof (1999) implemented an MR to estimate WTP for environmental services in a peat swamp forest, with reference to sport fishing in Sungei Karang, Malaysia. The results suggested that visitors with a higher level of education and a greater income had the tendency to register a higher WTP.

The model specification is shown in Table 4, which indicates the dependent and independent variables involved in this study. As shown, the dependent variable is the WTP (in Ringgit Malaysia) for an entrance permit. There are six predictor variables, varying in type of data, in this study. These variables have been included in this model for several reasons. First, they have been cited and discussed in the earlier literature. Second, some authors have used them in their studies. The selection of variables referred to in the literature is related to WTP, and these variables demonstrate the WTP of respondents. McCarville (1995) and More and Stevens (2000) found that socio-demographic characteristics such as income, age and education are correlated with opinions regarding pricing. On the other hand, Bowker et al. (1999) have used various socio-demographic variables including gender, education, household size, race, income and geography in their research to determine user fees. According to Williams et al. (1999) there is an association between income levels and fee support. As the income of respondents increases, levels of support for recreational programmes will increase. Income and age are in continuous data, while some of them, such as gender, nationality and marital status, are dichotomous. A further explanation is illustrated in Table 4.

WTP $=\mathrm{f}$ \{income, age, nationality, gender, marital status, education $\}$

or

WTP $=\beta_{0}+\beta_{1} x_{1}+\beta_{2} x_{2}+\beta_{3} x_{3}+\beta_{4} x_{4}+\beta_{5} x_{5}+\beta_{6} x_{6}+e_{i}$

where $\beta_{1}, \beta_{2}, \ldots \ldots . \beta_{6}$ are the model coefficients for the corresponding independent variables $x_{1}, . ., x_{6} . \quad e_{i}$ is the error term of the model, with an assumption of having $\mathrm{N}\left(0, \beta^{2}\right) ; i$ represents the respondent for $\mathrm{i}=1,2, \ldots, 196$. Finally, the list of independent variables is as follows:

$\mathrm{x}_{1}=$ monthly income

$\mathrm{x}_{2}=$ age 
$\mathrm{x}_{3}=$ nationality

$\mathrm{x}_{4}=$ gender

$\mathrm{x}_{5}=$ marital status

$\mathrm{x}_{6}=$ education level

Insert Table 4 about here

In this study, questionnaire was designed to gather information such as socio-demographic characteristics of respondents and WTP for entrance permit. The questionnaire was divided into three sections:

(a) Characteristics of visit

In this part, respondents were asked about their visits, preferences and facilities at TNNP.

(b) Contingent Valuation Method - Willingness to Pay

The respondents were asked how much they were willing to pay for entrance permit. The type of elicitation method used was open ended.

(c) Socio demographic characteristics

This section included questions about respondents' characteristics such as gender, age, marital status, nationality, education level and monthly gross income, purportedly to be common factors affecting WTP for entrance permit. Systematic sampling applied where the third visitors who entered the park were chosen as the sample. This technique was preferred because it was possible to get a precise sample and it was simple to practice. The survey was conducted at the gate of TNNP in two periods, 10 -17 March 2009 and 1-13 May 2009. The average time taken for the survey was about 20-30 minutes. A total of 229 respondents participated in this survey. Only, 196 respondents answered the questionnaire completely. Thus, the useable questionnaire was 196.

\section{Results and Discussion}

Table 5 displays the summary of visitors' profiles. Zaiton (2008) found $60 \%$ of visitors to TNNP were male. This study has similar findings; the majority of the visitors, $62.4 \%$ were male. It is found that $48.1 \%$ of visitors were married. Most of the visitors (47.1\%) were between 26 to 35 years old, followed by the age group 18 to 25 years old (31.9\%). Chin et al. (2000) found that 76.0 per cent of visitors to Bako National Park were aged between 16 and 40. In addition, Lindberg et al. (1998) where it was discovered that most of the visitors (89.0 per cent) to TNNP were in the age group below 40. All these findings suggest that the younger generation have a greater intention of visiting the tropical rain forests and national parks. More than half $(52.4 \%)$ of the visitors were international while the rest (47.6\%) were Malaysians. In terms of educational background, 25.7\% and 32.8\% of the visitors attained first degrees and masters/PhD, respectively. This study has similar finding with Zaiton (2008), Pau (1993) and Khoo (1995); found most visitors to TNNP are university educated. Travel Industry Association of America (TIAA, 1994) found that 35 per cent of ecotourists in the USA were in the professional/managerial occupation group. This study found most visitors $(32.9 \%)$ held professional jobs such as teachers and doctors, followed by managerial (31.0\%). In terms of income, $38.1 \%$ earned an income between US\$1001-US\$2000 followed by US\$2001-US\$2001-US\$3000, which is $21.4 \%$. Backman and Potts (1993) discovered that ecotourists earn a higher income than other travelers.

Insert Table 5 about here

Table 6 summarizes results of MR among visitors to TNNP. As expected, an increase in the monthly gross income would increase the WTP: a 1 per cent increase in visitors' income would increase WTP by an average of 0.1063 per cent. The positive sign of education means that an increase in number of years of education would increase their WTP. More specifically, a 1 per cent increase in years of education $\left(\mathrm{x}_{6}\right)$, it would increase WTP by an average of 0.3313 per cent. Income and education are among the most popular variables to describe the profile of any research sample. This model has discovered that these two variables have a significant relationship with respondents' WTP. It is found that an increase in income will result in a relatively low increase in WTP. On the other hand, an increase in education level relates to a higher increase in WTP. Income is therefore important, however, its effect is usually short-term. When we asked about income, people have to consider other expenses such as accommodation, food, etc. The effect of education on an individual is more lasting. As such it will increase his or her knowledge and may eventually have an impact on the thinking of a rational person. This normally will shape his perception and attitude in a more matured manner. Since what he learns is embedded in him as a person, the effect of education on his behaviour is usually quite strong, especially, if it is consistent with his perception such as the WTP. From the study, there is a possibility that the education of respondents had a strong contribution to respondents WTP. On the other hand, incomes of the respondents were not so high as to provide significant effects on the WTP.

In this study, both income and educational level were found to be significant variables in influencing the WTP. In terms of managerial implications, this information would be very helpful in focusing marketing strategies. It is obvious that the marketing effort should focus on targeting the people in the higher income bracket as well as those with higher educational achievement. These groups of people could be found living in the more affluent areas of any country; and they would usually be holding managerial positions within organizations. This study 
also found that nationality of visitors had a negative impact on WTP. This can be interpreted as follows: Malaysian visitors are less willing to pay compared to international visitors. Marital status also found to be significant in influencing WTP. It can be interpreted as married visitors are willing to pay more for entrance permit. This is because they want their children/grand children enjoy what they had enjoyed today such as scenic beauty of national park etc. In other words, we can say that they want to conserve the rain forest for future generation.

Insert Table 6 about here

\section{Conclusion and Discussion}

Studies on WTP will provide some guidelines on pricing strategy and give extra information for park management decisions, especially on park pricing. Information on issues such as factors influenced visitors WTP and socio-demographic and economic characteristics of visitors will provide a guideline and extra information for park authority, government, private sector and other stakeholders. The outcome of MR analysis in this study can be used as input in the planning process and some managerial policy implications The results of the study indicated that WTP for entrance permit influenced by visitors income, nationality, education level and marital status. Previous WTP studies in some national parks found that international visitors were willing to pay more for national park fees such as entrance permits and so did this study. Some national parks have used this information and implemented a dual pricing system; where international visitors have to pay more than local visitors. Income can be associated with nationality and education level. Most international visitors earned higher income involved currency exchange. Also, when somebody had a high level of education, most probably they will earn a high income. This study found that visitors within the high income bracket are willing to pay more for entrance permit. Therefore, TNNP's marketing campaigns and efforts can be targeted to the people who belong to the middle to higher income bracket.

This study also indicated that visitors with higher education are willing to pay more for entrance fees. TNNP can use information on respondents' education in designing marketing approach; focusing on this group. In other words, TNNP should target those in the higher education bracket in terms of promoting its products and services. TNNP should also implement education programmes that can increase the level of awareness among visitors. It is believed that visitors, who have the right information on park conservation etc, are more positive in their perception and decision especially those involving payment. In addition, products and services should contain some educational elements; contributing to knowledge and experience of the visitors. This does not mean that the lower educational group should not be completely left out.

It can be agreed that management plans supported by research such as this will be more credible and the management can use it to justify any changes such as increase in fees to the authorities. These findings can assist TNNP to design the most appropriate fee structure, both for the visitors and to meet its own objectives. TNNP should instead, focus on visitors in the high education bracket in designing their target market. Understanding all information above not only will create an efficient park management through efficient pricing system, it will also contribute to the long-term sustainable development of TNNP.

\section{References}

Backman, K. F., and Potts, T. D. (1993). Profiling nature-based travelers: Southeastern market segments. South Carolina: Strom Thurmond Institute.

Bowker, J. M., Cordell, H. K., and Johnson, C. Y. (1999). User fees for recreation services on public lands: A national assessment. Journal of Park and Recreation and Administration, 17(3), 1-14.

Bryman, A., and Cramer, D. (2001). Quantitative data analysis with SPSS 10 for Windows: A guide for social scientists. London: Routledge.

Cameron, T. A. (1988). A new paradigm for valuing non-market goods using referendum data: maximum likelihood estimation by censored logistic regression. Journal of Environmental Economics and Management, 15, 355-379.

Chin, C. L. M., Moore, S. A., Wallington, T. J., and Dowling, R. K. (2000). Ecotourism in Bako National Park, Borneo: Visitors' perspectives on environment impacts and their management. Journal of Sustainable Tourism, $8(1), 20-35$.

DWNP (1986). Development plan for Kuala Tahan and adjacent areas. Taman Negara Master Plan. Kuala Lumpur: Department of Wildlife and National Parks.

DWNP (1987). Taman Negara master plan. Kuala Lumpur: Department of Wildlife and National Parks.

DWNP (2005). Annual Report 2003. Kuala Lumpur: Department of Wildlife and National Parks.

Ismail, M. Z. (1984). Checklist of fishes of Taman Negara. Malayan Naturalist, 37(3), 21-26.

Khan, M. K. (1971). The distribution of large mammals in Taman Negara. Malayan Nature Journal, 24(3and4), 125-131.

Khoo, A. (1995). A study of visitors to Taman Negara. Kuala Lumpur: DWNP. 
Kochummen, K.M. (1990). Wild fruits trees of Taman Negara. In Y.H. Sen ( Eds.). A special issue to commemorate the golden jubilee of Taman Negara. The Journal of Wildlife and Parks, Malaysia. X:30-33.

Kosz, M. (1996). Valuing riverside wetlands: the case of the 'Donau-Auen' national park. Ecological Economics, $16,109-127$.

Lim, B. L. and Anan, S. (1990). Small mammals of Taman Negara. In Y. H. Sen (Eds.) A special issue to commemorate the golden jubilee of Taman Negara. The Journal of Wildlife and Parks, Malaysia. X:148-152.

Lindberg, K., Furze, B., Staff, M., and Black, R. (1998). Ecotourism in the Asia-Pacific Region: Issues and outlook. Rome: United Nations Food and Agriculture Organization.

Lindsey, G., and Holmes, A. (2002). Tourist support for marine protection in Nha Trang, Viet Nam. Journal of Environmental Planning and Management, 45(4), 461-480.

Mathews, L.G., Kask, S., Rotegard, L. and Stewart, S. (2001). Using economics to inform national park management decisions: A case study on the Blue Ridge Parkway. Retrieved April 13, 2010 from http:///www.georgewright.org/56mathew.pdf

McCarville, R. E. (1995). Pricing for public leisure services: An ethical dilemma? Journal of Park and Recreation Administration, 20(2), 95-108.

Mitchell, R. C., and Carson, R. T. (1989). Using Surveys to Value Public Goods: the Contingent Valuation Method (Resources for the Future). Washington, D.C.

Mohd Shahwahid, H..O. and Mahamad Yusof, A.R. (1999). Sport fishing recreational services by peat swamp forests. Manual on Economic Valuation of Environmental Goods and Services of Peat Swamp Forests. Kuala Lumpur: DANCED.

More, T., and Stevens, T. (2000). Do user fees exclude low-income people from resource based recreation? Journal of Leisure Research, 32(9), 341-357.

Pau, G. M. (1993). Pre and post visit perceptions on Taman Negara. Faculty of Forestry, Universiti Pertanian Malaysia. 96 pp.

Rubeli, K. (1976). Taman Negara - present demands and future pressures. Malayan Nature Journal, 29(4), 204-245.

Soepadmo, E. (1971). Plants and vegetation along the paths from Kuala Tahan to Gunung Tahan. Malayan Nature Journal, 24 (3and4), 118-124.

Tabachnick, B. G., and Fidell, L. S. (2001). Using multivariate statistics (4th ed.). New York: Harper Collins.

Tisdell, C., and Wilson, C. (2000). Wildlife-based tourism and increased support for nature conservation financially and otherwise: evidence from sea turtle ecotourism at Mon Repos. Journal of Tourism Economics, 7(3), 233-250.

Travel Industry Association of America (TIAA) (1994). Adventure travel: Profile of a growing market, conducted by US Travel Data Center, Washington, DC.

White, P. C. L., and Lovett, J. C. (1999). Public preferences and willingness to pay for nature conservation in the North York Moors National Park, UK. Journal of Environmental Management, 55, 1-13.

Williams, D. R., Vogt, C. A., and Vitterso, J. (1999). Structural equation modelling of users' response to wilderness recreation fees. Journal of Leisure Research, 31(3), 245-268.

Woehr, D. J., and Cavell, T. A. (1993). Self-report measures ability, effort and non-academic activity as predictors of introductory psychology test scores. Teaching of Psychology, 20, 156-160.

Zaiton, S. (2007). Willingness to Pay in a National Park in Malaysia: A Case Study of Taman Negara. Unpublished Ph.D. dissertation, University of Exeter. UK.

Zaiton, S. (2008). Willingness to Pay in Taman Negara: A Contingent Valuation Method. International Journal of Economics and Management, 2 (1): 81-94.

Table 1: Malaysian and International Visitors to TNNP, 2001 - 2009

\begin{tabular}{cccc}
\hline Year & Malaysian visitors & International visitors & Total \\
\hline 2001 & 26149 & 32383 & 58532 \\
2002 & 30108 & 30048 & 60156 \\
2003 & 33326 & 20904 & 54230 \\
2004 & 31233 & 28793 & 60026 \\
2005 & 37819 & 33812 & 71631 \\
2006 & 40877 & 38881 & 8758 \\
2007 & 40358 & 41616 & 84142 \\
2008 & 39579 & 44563 & 86674 \\
2009 & 40617 & 46057 & \\
\hline
\end{tabular}


Table 2: International Visitors Arriving at TNNP by Country, 2009 (Top 5)

\section{Country}

Number of Visitors

1. Holland

10421

2. United Kingdom

5204

3. Germany

4971

4. France

4080

5. Singapore

2607

Source: DWNP, 2010.

Table 3: Charges of Permits and Licences at TNNP

\section{Permit and licences}

1. Entrance permit

2. Fishing licence

3. Camera licence

4. Camping fee

5. Canopy walkway

6. Hide

\section{Charges (RM)}

RM1/entry

RM10/person

RM5/camera

$\mathrm{RM} 1 /$ day/person

RM5/person

RM5/person/night

Source: DWNP, 2005.

Table 4: Definition of Variables in MR Model

\begin{tabular}{|c|c|c|c|}
\hline Variable Name & Type of & Type of Data & Definition \\
\hline 1. WTP & Dependent & Ratio & $\begin{array}{l}\text { Maximum value of willingness to pay } \\
\text { for entrance permit in RM. }\end{array}$ \\
\hline 2. Income & Independent & Ratio & $\begin{array}{l}\text { Monthly gross income in Ringgit } \\
\text { Malaysia. }\end{array}$ \\
\hline 3. Age & Independent & Ratio & Age in years. \\
\hline 4. Nationality & Independent & Dichotomous & $\begin{array}{l}\text { Dummy variable for nationality: } 1= \\
\text { Malaysian, } 0=\text { Otherwise }\end{array}$ \\
\hline 5. Gender & Independent & Dichotomous & $\begin{array}{l}\text { Dummy variables for gender: } \\
1=\text { male, } 0=\text { female }\end{array}$ \\
\hline 6. Marital status & Independent & Dichotomous & $\begin{array}{l}\text { Dummy variables for marital status: } 1 \\
=\text { married, } 0=\text { others }\end{array}$ \\
\hline 7. Education & Independent & Ordinal & Education level \\
\hline
\end{tabular}

Source: Authors (2009). 
Table 5. Profile of Visitors

\begin{tabular}{|c|c|c|}
\hline Characteristics & Percentage & $\mathbf{n}$ \\
\hline \multicolumn{3}{|l|}{ Gender } \\
\hline Male & 62.4 & 131 \\
\hline Female & 37.6 & 79 \\
\hline \multicolumn{3}{|l|}{ Marital status } \\
\hline$\overline{\text { Single }}$ & 47.6 & 100 \\
\hline Married/partner & 48.1 & 101 \\
\hline Prefer not to say & 4.3 & 9 \\
\hline \multicolumn{3}{|l|}{ Age } \\
\hline$\overline{18-25}$ & 31.9 & 67 \\
\hline $26-35$ & 47.1 & 99 \\
\hline $36-45$ & 10.5 & 22 \\
\hline $46-55$ & 7.6 & 16 \\
\hline $56-65$ & 2.4 & 5 \\
\hline $65+$ & 0.5 & 1 \\
\hline \multicolumn{3}{|l|}{ Nationality } \\
\hline$\overline{\text { Malaysian }}$ & 47.6 & 100 \\
\hline International & 52.4 & 110 \\
\hline \multicolumn{3}{|l|}{ Education level } \\
\hline No formal education & 2.4 & 5 \\
\hline Primary school & 2.4 & 5 \\
\hline Secondary school & 16.7 & 35 \\
\hline Diploma & 25.7 & 54 \\
\hline First degree & 32.8 & 69 \\
\hline Masters/PhD & 20.0 & 42 \\
\hline \multicolumn{3}{|l|}{ Occupation } \\
\hline$\overline{\text { Professional }}$ & 32.9 & 69 \\
\hline Managerial & 31 & 65 \\
\hline Skilled non-manual & 7.6 & 16 \\
\hline Skilled manual & 4.8 & 10 \\
\hline Unskilled non-manual & 2.4 & 5 \\
\hline Retired & 2.8 & 6 \\
\hline Student & 14.3 & 30 \\
\hline $\begin{array}{l}\text { Not working for medical } \\
\text { reasons }\end{array}$ & 0.9 & 2 \\
\hline Unemployed & 3.3 & 7 \\
\hline \multicolumn{3}{|l|}{ Monthly gross income } \\
\hline$\overline{\text { Lower than US\$1000 }}$ & 18.6 & 39 \\
\hline US\$1001 - US\$2000 & 38.1 & 80 \\
\hline US\$2001 - US\$3000 & 21.4 & 45 \\
\hline US\$3001 - US\$4000 & 9.0 & 19 \\
\hline US\$4001 - US\$5000 & 6.2 & 13 \\
\hline More than US\$5000 & 6.7 & 14 \\
\hline
\end{tabular}

Source: Author survey (2009) 
Table 6. Results of MR

\begin{tabular}{cc}
\hline Variable & Model WTP \\
\hline Constant & -0.2314 \\
& $(-0.3515)$ \\
Monthly income & $0.1063^{*}$ \\
& $(2.8601)$ \\
Age & 0.2282 \\
& $(1.0695)$ \\
Nationality & $-0.6474 * *$ \\
& $(-4.8925)$ \\
Gender & 0.0378 \\
& $(0.3487)$ \\
& $0.2601 *$ \\
Marital status & $(2.3893)$ \\
& $0.3313^{*}$ \\
Education & $(2.4181)$ \\
& \\
\hline R-Square & \\
Adjusted R & 0.3525 \\
d.f. & 0.3319 \\
& 17.1469 \\
& 195 \\
\hline
\end{tabular}

Note: Values in parentheses are the corresponding t-statistic, that is, coefficient divided by its standard error. $* \rho \leq 0.05$

$* * \rho \leq 0.01$ 